
c
i
$R$
C
L E
LUND
UNIVERSITY

\title{
Entrepreneurial Experimentation: A key function in Entrepreneurial Systems of Innovation
}

Åsa Lindholm-Dahlstrand (asa.lindholm_dahlstrand@circle.lu.se)
CIRCLE, Lund University, Sweden
Martin Andersson (martin.andersson@bth.se)

Blekinge Institute of Technology (BTH) \& CIRCLE, Lund University, Sweden

Bo Carlsson (bo.carlsson@case.edu)

Case Western Reserve University, US \& CIRCLE, Lund University, Sweden

Papers in Innovation Studies

Paper no. 2016/20

This is a pre-print version of a paper that has been submitted for publication to a journal.

This version: June 2016

Centre for Innovation, Research and Competence in the Learning Economy (CIRCLE)

Lund University

P.O. Box 117, Sölvegatan 16, S-221 00 Lund, SWEDEN

http://www.circle.lu.se/publications 


\title{
Entrepreneurial Experimentation: A key function in Entrepreneurial Systems of Innovation
}

\author{
Åsa Lindholm-Dahlstrand, Martin Andersson, Bo Carlsson
}

\begin{abstract}
There is a need for a conceptual approach that, with reference to explicit microlevel mechanisms and processes of industrial dynamics, articulates the role and function of entrepreneurial experimentation in innovation systems. This paper develops the concept of 'entrepreneurial systems of innovation' to address this gap in the literature. We argue that entrepreneurial experimentation comprises both 'technical' and 'market' experimentation, and that entrepreneurship must be conceptualized in terms of its function in innovation systems rather than as an outcome. At the systems level, the central function of entrepreneurial experimentation is to foster creation, selection and scaling-up of innovations. Spinoffs and acquisitions are proposed as examples of micro-mechanisms that give rise to system-wide entrepreneurial experimentation. Interaction between established organizations and new innovative entrants, through spinoffs and acquisitions, is an important characteristic of vibrant entrepreneurial systems of innovation.
\end{abstract}

Keywords: entrepreneurship; experimentation; innovation systems; new technologybased firms; entrepreneurial systems of innovation; scaling up; growth

JEL: O31; O33; L22; L26

Disclaimer: The authors are fully and solely responsible for the content of this working paper which does not necessarily represent the opinion of CIRCLE. 


\title{
ENTREPRENEURIAL EXPERIMENTATION
}

\author{
A key function in Entrepreneurial Systems of Innovation
}

\author{
Åsa Lindholm-Dahlstrand ${ }^{\mathrm{a}}$, Martin Andersson ${ }^{\mathrm{b}}$ and Bo Carlsson ${ }^{\mathrm{c}}$
}

\begin{abstract}
There is a need for a conceptual approach that, with reference to explicit micro-level mechanisms and processes of industrial dynamics, articulates the role and function of entrepreneurial experimentation in innovation systems. This paper develops the concept of 'entrepreneurial systems of innovation' to address this gap in the literature. We argue that entrepreneurial experimentation comprises both 'technical' and 'market' experimentation, and that entrepreneurship must be conceptualized in terms of its function in innovation systems rather than as an outcome. At the systems level, the central function of entrepreneurial experimentation is to foster creation, selection and scaling-up of innovations. Spinoffs and acquisitions are proposed as examples of micromechanisms that give rise to system-wide entrepreneurial experimentation. Interaction between established organizations and new innovative entrants, through spinoffs and acquisitions, is an important characteristic of vibrant entrepreneurial systems of innovation.
\end{abstract}

JEL: O31, O33, L22, L26

Keywords: entrepreneurship, experimentation, innovation systems, new technologybased firms, entrepreneurial systems of innovation, scaling up, growth

\footnotetext{
${ }^{\mathrm{a}}$ CIRCLE (Centre for Innovation, Research and Competence in the Learning Economy), Lund University, Lund, Sweden. E-mail: asa.lindholm_dahlstrand@ @ircle.lu.se

${ }^{\mathrm{b}}$ Department of Industrial Economics, Blekinge Institute of Technology (BTH), Karlskona / Research Institute of Industrial Economics (IFN), Stockholm, / CIRCLE, Lund University. E-mail: martin.andersson@bth.se

${ }^{c}$ Department of Economics, Weatherhead School of Management, Case Western Reserve University, US and CIRCLE, Lund University. E-mail: bo.carlsson@ case.edu
}

Notes and acknowledgements: Authors in no particular order - all authors contributed equally . This research was supported by the Swedish Research Council (VR) grant 2013-994. We acknowledge constructive comments from Torben Schubert, Jing Xiao, Jonas Gabrielsson, Diamanto Politis as well as comments and suggestions from participants at the 2016 Eu-SPRI conference on "Exploring new avenues for innovation and research policies" at CIRCLE, Lund University. 


\section{INTRODUCTION}

This paper introduces the concept of 'entrepreneurial systems of innovation' as an analytical and conceptual approach to understand the workings of entrepreneurial experimentation in innovation systems, and how this experimentation feeds the systems' capacity to generate innovations and economic growth. While linking up to established work on national innovation systems (Lundvall 1985, Freeman 1987, Edquist 1997), national systems of entrepreneurship (Acs et al 2014) and entrepreneurial eco-systems (Mason and Brown 2014, Stam and Spigel 2016, Stam 2015), the framework developed in this paper is different. Most of the work on innovation systems, including the more recent entrepreneurial ecosystems literature, is policy-oriented and primarily concerned with understanding how innovation and entrepreneurship is determined. Our aim is instead to articulate the function of entrepreneurship and entrepreneurial experimentation (cf. Bergek et al 2008) in innovation systems and economic growth. ${ }^{1}$

Our starting point is that entrepreneurship is a key process in which new technologies and new knowledge are converted into innovations that drive growth (Acs et al 2009, Braunerhjelm et al 2010). Innovation systems approaches that do not embed and explicate this function will therefore never be able to explain how systems of innovation generate growth. As shown by Braunerhjelm and Henrekson (2016), a main challenge concerns the constituent parts of an institutional framework that connects knowledge and entrepreneurial effort in promoting growth. To facilitate such a connection, they argue, Schumpeterian entrepreneurship must be given a central role. In a similar manner, we claim that understanding and articulating the function that entrepreneurship and entrepreneurial experimentation has in innovation systems requires a systems framework that is built from the micro level and embeds a Schumpeterian micro-based theory of entrepreneurial experimentation.

We depart from Carlsson's and Eliasson's (2003) theory of the experimentally organized economy (EOE), which outlines a framework for micro-based endogenous growth. A key idea in this framework is that economic growth is a result of experimental project creation (technologies) and selection in dynamic markets and hierarchies, and of the capacity of the economic system to capture winning businesses and innovations, while letting go of losing ones. It thus has a two-pronged focus: (i) creation of variety of new technologies and ideas, and (ii) selection and retention of "winning" innovations in the form of commercialization of new technologies. The selection process may be thought of as a kind of sorting or filtering process, in which viable and innovative high-impact businesses and innovations are selected by market forces and scaled up.

\footnotetext{
${ }^{1}$ This is not to say to the framework developed in this paper lacks policy implications. However, the main purpose here is to develop a framework to understand the function of entrepreneurial experimentation in entrepreneurial innovation systems.
} 
Based on the EOE framework, we argue that the central function of entrepreneurial experimentation in innovation systems is to foster creation, selection and scaling-up of innovations. Entrepreneurial experimentation relates both to the "supply-side", in terms of the system's capacity to develop variety of new technologies and business ideas that become subject to selection, as well as to the "demandside", in terms of the efficiency of selection and scaling up of innovations and businesses on the market.

The need for technical experimentation on the supply-side is required because of genuine Knightian uncertainties (Knight 1921) regarding which technologies may be useful and feasible. ${ }^{2}$ A large variety of projects raises the odds of developing and selecting "good" technologies, i.e. it is not known a priori which technologies that turn out to be important innovations (commercialized technologies). Likewise, experimentation is crucial in the selection stage (Kerr et al. 2014). For a given new technology, there are often no established business models or markets, no well-defined areas of implementation and there is uncertainty about synergies with existing technologies and products (Kemp et al 1998). No single Schumpeterian entrepreneur (in new or established firms/organizations) knows beforehand 'what works'; nor can knowledge of business models, markets niches and areas of technology implementation easily be deduced from some set of first principles. This comes to show that entrepreneurial experimentation is crucial in the innovation process itself ("technical experimentation") as well as in the entrepreneurial activity to which it may give rise.

Against this backdrop, we hold that the function of entrepreneurship is at the systems level fundamentally about experimentation, and that entrepreneurial experimentation therefore must be a key element of the domains of innovation systems and entrepreneurship research. Dynamic innovation systems, which feed innovation and growth, must promote or at least accommodate entrepreneurial experimentation. This forms the conceptual basis for the concept of "Entrepreneurial systems of innovation".

Entrepreneurial experimentation may be conceived of as part of the absorptive capacity within the system, consisting of receptivity to new technologies, ideas as well as the ability to act and experiment on them. Similar to Shane's (2000) argument about the discovery of entrepreneurial opportunities, it is possible that limited technological change generates large economic output because entrepreneurs

\footnotetext{
${ }^{2}$ As an example, Gordon Moore, co-founder of Fairchild semiconductors, has explained that one of the biggest mistakes he made while working at Fairchild was to not recognize the importance and general applicability of integrated circuits. He has stated (Moore and Davis 2004, p27-28): "Most of us working in the laboratory ... did not realize at first that we had barely scratched the surface of a technology that would be so important. It was just another product completed, leaving us looking around for a new device to make, wondering, 'what's next?"' (as cited in Klepper 2016).
} 
experiment with different ways to exploit new technology. Conversely, significant technological change might generate limited economic output because of lack of entrepreneurial experimentation. Not only the discovery of opportunity, but also the decision to exploit opportunity, is crucial for entrepreneurial experimentation to take place (Schumpeter 1934). Policy-wise, this perspective naturally entails a focus on institutions and incentive structures that stimulate actors (firms, individuals, organizations) to undertake actions that foster entrepreneurial experimentation (Carlsson and Eliasson 2003

A meaningful concept of entrepreneurial systems of innovation must however not just make the point that entrepreneurial experimentation is important. There is a need to explicate the systems features that lead to and stimulate entrepreneurial experimentation. A common critique of the traditional innovation systems literature is indeed that is stresses feedback loops and interdependencies, but is rather vague on where those effects come from, how they are materialized as well as how they are linked to behaviors and incentives of actors in the system (Braunerhjelm and Henrekson 2016).

Given our definition of the function of entrepreneurial experimentation, our task is to articulate and specify actors and respective actions involved in the three central processes, i.e. creation, selection and scaling-up of innovations, within a given institutional setting. We also need to specify at the micro level - in terms of actors and actions - how the three processes link up to and feed each other in interdependent ways; it is such interaction that motivates the systems perspectives.

To this end, we put entrepreneurship and experimentation at center stage and develop our framework by stressing the interaction and symbiosis between new technology-based firms and established businesses and universities. ${ }^{3}$ We identify two examples of critical mechanisms - spin-off and acquisition - that drive entrepreneurial experimentation in the system. Both are examples of mechanisms that are relevant in high-technology and knowledge-intensive contexts (see e.g. Norbäck and Persson 2004, Gans amd Stern 2003, Andersson and Xiao 2016, Xiao 2015). They also bear directly on a systems' capacity to (i) create new technology and products (creation), (ii) experiment with regard to their applicability in various market and business contexts (selection) and (iii) to scale up the commercial potential by embedding new technology and innovations into global sales networks and value chains (scaling-up).

\footnotetext{
${ }^{3}$ From this perspective our framework touches base with the technological systems literature (Carlsson and Stankiewicz 1991). While much of the innovation systems literature focuses on nations, regions, or sectors as the unit of observation (leaving no room for entrepreneurial activity), the technological innovation systems concept is based on individual firms and technologies and recognizes that it is their interaction that drives the system forward, provided that the institutional arrangements are appropriate.
} 
In short, we argue that spinoffs and acquisition constitute examples of micro-level mechanisms and processes of industrial dynamics that give rise to system-wide entrepreneurial experimentation that fosters creation, selection and scaling up of new technology and innovations. Our line of reasoning may be summarized as follows: most knowledge creation activities, for example in terms of R\&D, occur in established firms and in academic institutions (Carlsson et al., 2009). They are thereby direct as well as indirect sources of new technologies. Entrepreneurship is a mechanism (or function) by which knowledge and technologies developed in these 'sources' are brought to the market, such that new technologies and ideas become subject to selection. Commercialization takes place when incumbent firms via expansion of existing lines of business and creation of new business lines (intrapreneurship or corporate venturing), or when employees leave their employer (corporate spinoff) to found a new technology-based firm based on knowledge and ideas acquired in the firm. Commercialization of academic research takes place via start-ups (academic spinoffs) or licensing to existing firms. This is the process of creation. Selection occurs at many levels in the market, by consumers, venture capitalists and so on.

One specific form of selection that we focus on as an example is acquisition. Established firms purposefully select pertinent acquisition targets. When targets are technology-based new firms, the incentive for acquisition on behalf of the acquiring firm is often to embed their technologies, products or services in existing systems and sales networks, or to strengthen their technological or knowledge assets. From the point of view of the founders of new firms, they and their organizations typically lack the human capital and financial resources needed to scale up their innovations and to fully exploit their commercial potential. Such resources therefore have to be acquired from outside, for example by being acquired by an established business. This implies that many entrepreneurs have an incentive to be acquired. For example, Baumol (2002) argues that the different roles of new and established firms may be described as a "David-Goliath symbiosis". New and small firms are more likely to develop radical innovations and technologies but lack resources to scale up. Established firms with global sales networks and resources, such as multinational corporations, can enhance or embed the novelties developed by small entrants into existing products and production processes and bring them to a global scale. Acquisition of innovative entrants is one way in which the complementary roles may be realized, and thus exemplifies one form of interaction between new technology-based firms and established firms that could contribute to system-wide innovativeness and economic growth.

To motivate our case in point, we draw on three main sets of literatures: the innovation systems literature (Lundvall 1992, Nelson 1993), the literature on the origins of new technology-based firms and university and corporate spinoffs (Andersson and Klepper 2013, Lindholm Dahlstrand 1997, 1999, 2009, Klepper 2016), the literatures on commercialization strategies of innovative start-ups (Norbäck and Persson 2014, Gans and Stern 2003), and the symbiosis between established and large 
firms (Baumol 2002, Lindholm Dahlstrand 1997, 1999, 2009, Andersson and Xiao 2016). Insights from these literatures allow us to articulate what makes the system in the sense that we introduce spinoffs and acquisitions as distinct functions that are directly linked to behaviors and incentives of well-defined actors. We also elucidate how these functions are related to system-wide entrepreneurial experimentation and how they induce feedback effects and interdependencies in system-wide entrepreneurial experimentation which defines an entrepreneurial system of innovation capable of generating innovations and economic growth.

The paper is organized as follows. In the next section, we review extant perspectives on Systems of Innovation and identify important implications of the differences between them. In the third section, we describe the role of entrepreneurial experimentation in the Entrepreneurial System of Innovation. This includes proposing two key mechanisms for the entrepreneurial experimentation. We propose that spin-offs and acquisitions are key for a successful entrepreneurial experimentation and the dynamics of innovation systems. In the final section, we discuss the implications of these suggestions and propositions for innovation and entrepreneurship research and practice.

\section{ENTREPRENEURSHIP AND ENTREPRENEURS IN SYSTEMS OF INNOVATION}

\subsection{A brief overview of the innovation systems literature}

'Innovation system' is a concept that has diffused rapidly since its introduction in the middle of the 1980s (Lundvall 1985). The concept of 'National Systems of Innovation' (NIS) was first used by Freeman (1987) in his work on innovation in Japan. The main theoretical underpinnings were that knowledge is a fundamental resource in the economy, that knowledge is produced and accumulated through an interactive and cumulative process of innovation that is embedded in a national institutional context, and that the context therefore matters for innovation outcomes (Lundvall, 1999). The traditional innovation system approach focuses on the components within the systems, i.e. organizations and institutions. Organizations are the players or actors, while institutions are the rules of the game (Edquist 1997, Lundvall 1992, Nelson 1993, Breschi and Malerba 1997, Malerba 2004). This is consistent with the notion of 'players' and the 'rules of game' addressed by North (1990). The 'innovation system' concept can also be understood in a narrow as well as in a broad sense (Lundvall, 1992). The narrow approach concentrates on those institutions which deliberately promote the acquisition and dissemination of knowledge. The "broad" approach recognizes that these "narrow" institutions are embedded in a much wider socio-economic system. 
Much of this literature insists on the central importance of national systems, but a number of authors have argued that globalization has greatly diminished or even eliminated the importance of the nation state (Freeman 2002). Several alternative concepts have emerged that emphasize the systemic characteristics of innovation but concern other levels than the nation state. Sometimes the focus is on a particular country or region, which then determines the spatial boundaries of the system. For example, the literature on 'regional systems of innovation' (RIS) has grown rapidly since the middle of the 1990s (cf. e.g. Cooke 1996, Maskell and Malmberg 1999), and Carlsson (2006) shows that the majority of theoretical as well as empirical analyses of innovation systems have a regional focus. In other cases, the main dimension of interest is a sector or technology. Usually these different concepts and dimensions reinforce each other and do not need to be in conflict.

In contrast to the NIS and RIS approaches, the literature on technological innovation systems (TIS) takes into account factors that are unique to a knowledge field. In the TIS concept's early development stages, it became clear that although national-level features were significant, diverse technological areas included different settings and dynamics (Carlsson et al. 2009). Carlsson and Stankiewicz (1991) define a technological innovation system as a network of agents interacting in a specific economic/industrial area under a particular institutional infrastructure or set of infrastructures and involved in the generation, diffusion, and utilization of technology. In order to transform knowledge into economic activity, entrepreneurial activity (experimentation) is required. TIS are defined in terms of knowledge/competence flows rather than flows of ordinary goods and services, and focuses on a knowledge field or product including an interacting group of components. They are multi-dimensional, and incorporate components that are spatially correlated; regionally, nationally as well as globally. These components are actors (such as firms or universities), the technology (such as artefacts or coded and embodied knowledge), institutions (legal and regulatory aspects, culture and beliefs) and networks (such as political or learning networks). The structural elements, with exogenous factors such as financial or environmental crises, shape system dynamics.

To gain a better understanding of TIS dynamics, the 'functional dynamics' of TIS was developed, building on a scheme of key sub-processes in the larger process of innovation and diffusion (Bergek et al. 2008, Hekkert et al. 2007, Jacobsson and Bergek 2004, Johnson and Jacobsson 2001). The subprocesses (or sub-functions, Markard and Truffer 2008) include (Bergek et al. 2008):

- Knowledge development and diffusion (normally placed at the heart of a TIS)

- Influence on the direction of search (different competing technologies, applications, markets, business models, etc) 


\section{- Entrepreneurial experimentation}

- Market formation (actual market development and what drives market formation)

- Legitimation (social acceptance and compliance with relevant institutions. Formed through conscious actions by various organizations and individuals which eventually may help the new TIS to overcome its "liability of newness")

- Resource mobilization (competence/human capital, financial capital and complementary assets such as complementary products, services, network infrastructure, etc.)

- Development of positive externalities (pooled labor markets, specialized intermediate goods and service providers, information flows and knowledge spill-overs)

Bergek et al (2008) argue that a TIS without vibrant experimentation will stagnate. It should be noted that the word "entrepreneurial" does not refer only to new or small firms, but to the more general Schumpeterian notion of an "entrepreneurial function" (i.e. making new combinations). This function may be filled by any type of actor, including large, established firms diversifying into the new technology (Bergek et al 2008). But, even if the importance of entrepreneurial experimentation is recognized, there is a limited discussion of the individual.

\subsection{Introducing entrepreneurs and entrepreneurship}

Although the systems of innovation literature is influenced by the Schumpeterian tradition, the entrepreneur has remained rather absent in this literature. ${ }^{4}$ With its focus on structure, it tends to overlook the role of entrepreneurship and individual agency in driving innovation (Acs et al. 2014, Bergek et al 2008, Braunerhjelm and Henrekson 2016). One exception is the TIS literature as introduced by Carlsson and Stankiewicz (1991). They explicitly recognized that entrepreneurs are necessary and that entrepreneurs help to transform networks of agents into so-called development blocks understood as "synergistic clusters of firms and technologies within an industry or group of industries" (ibid, p. 111). Still, in the bulk of the innovation systems literature, in particular NIS, entrepreneurs and entrepreneurship are absent. The NIS literature is rooted in the Schumpeter Mark II tradition, which emphasize the role of large corporations in R\&D (Freeman and Soete 1997).

\footnotetext{
${ }^{4}$ In fact, despite the common roots in Schumpeter and some interrelated topics such as innovation management and technology-based firms, 'entrepreneurship' and 'innovation' have evolved as two largely separate research fields (Landström et al. 2012). While the innovation systems literature has taken a broad systems perspective, the entrepreneurship literature has not systematically considered the wider, system-level constraints and outcomes of entrepreneurial action (Acs et al 2014).
} 
Schumpeter's earlier ideas (Mark I) of entrepreneurs as agents of creative destruction have not been incorporated into the general framework (Acs et al 2014).

One reason for the lack of discussion of entrepreneurs in studies of innovation systems is its system-wide perspective in which individual traits, personalities and behavior in the innovation process carry little weight (Qian et al 2013). Also, it does not address new firm formation as an important manifestation of entrepreneurial activity. Its primary focus has instead been on $R \& D$ and other knowledge investment activities in incumbent firms and universities (Acs et al 2014). Qian et al (2013) argue that the insufficient investigations of entrepreneurs and new firms in the literature of innovation systems call for developing a systems approach to entrepreneurship. In making an effort toward this, they define systems of entrepreneurship as "those economic, social, institutional and all other important factors that interactively influence the creation, discovery and exploitation of entrepreneurial opportunities" (ibid, p.562).

An emerging literature focusing the wider system-level conditions and outcomes of entrepreneurial processes has been developed. This literature has mainly followed three paths:

i) Entrepreneurial Ecosystems (e.g. Mason and Brown 2014, Stam 2015) - sees entrepreneurs as the central actors. Argues that entrepreneurship, in the form of new high growth firms, is not only a result of the ecosystem, but also that entrepreneurs are central actors who help to build and shape the system. Focuses on the role of the context (often local) in stimulating or inhibiting entrepreneurship (Stam 2015). ${ }^{5}$

ii) National Systems of Entrepreneurship (eg Acs et al 2014) - system is defined as ".... the dynamic, institutionally embedded interaction between entrepreneurial attitudes, ability, and aspirations, by individuals, which drives the allocation of resources through the creation and operation of new ventures" (ibid, p.479) The focus is on the individual entrepreneur in the national cultural and institutional context.

iii) Entrepreneurial Propensity of Innovation Systems (Radosevic and Yoruk 2013) Knowledge intensive entrepreneurship (KIE) is embedded in IS, which is composed of heterogeneous actors and networks of various types and is shaped by institutions

\footnotetext{
${ }^{5}$ The most precise definition of entrepreneurial eco-systems is provided by Stam and Spigel (2016): "A set of interdependent actors and factors coordinated in such a way that they enable productive entrepreneurship within a particular territory".
} 
(regulatory systems). The focus is on innovation/technology and the national context, with limited links to entrepreneurship and individuals.

All three paths contribute to the development of a theory of an Entrepreneurial System of Innovation. Radosevic and Youruk (2013) base their ideas on the functioning of technological systems, where entrepreneurial experimentation is a key function of the system. However, the individual is not given much consideration, and they argue that entrepreneurial activities and entrepreneurial propensity are caused by structural features of the innovation system; that is, they emphasize macro-level conditions that influence entrepreneurial activities. This rather abstract treatment of entrepreneurs may be criticized on the grounds that it precludes the consideration of the origins and regulators of individual agency (Acs et al 2014). However, Van de Ven (1993) argues that the study of entrepreneurship is deficient if it focuses exclusively on the characteristics and behaviors of individual entrepreneurs, on the one hand, and if it treats the social, economic, and political infrastructure for entrepreneurship as exogenous on the other hand.

Acs et al (2014) maintain that any definition of National Systems of Entrepreneurship should recognize that entrepreneurship is fundamentally individual-level behavior; which mobilizes resources for opportunity pursuit through the creation of new firms; which is driven by complex population-level interactions between attitudes, aspirations, and ability; which is embedded within a multifaceted economic, social, and institutional context; and which drives economic productivity through the allocation of resources to efficient uses. However, in their empirical analysis they try to measure and compare National Systems of Entrepreneurship as a dynamic interaction between entrepreneurial attitudes, ability, and aspirations; within their institutional contexts, thus, largely ignoring processes of, for example, knowledge creation and technical experimentation in the system. In a sense, they go directly from the individual to the macro level and do not elucidate the processes of industrial dynamics that connect individual entrepreneurial efforts to innovation and economic growth.

Our reading of the current literature aiming to bring entrepreneurship and entrepreneurs into the innovation systems literature leads us to conclude that it still does not articulate the role of entrepreneurs and entrepreneurship. The role of entrepreneurship or entrepreneurial experimentation in fostering creation, selection and scaling up of new technologies and innovations, i.e. the functions that we deem central in an innovation system capable of generating innovations and economic growth, is neither acknowledged nor conceptually developed.

In particular, we know of no contribution that, based on explicit micro-level mechanisms and processes of industrial dynamics, articulates how the behavior of entrepreneurs and entrepreneurship give rise to system-wide entrepreneurial experimentation that fosters creation, selection and scaling up 
of new technology and innovations. It is this gap in the literature that we aim to address. As we will see, we argue that this requires a recognition of that entrepreneurial experimentation comprises both 'technical' and 'market' experimentation. It also requires that entrepreneurship is analytically conceptualized in terms of its function in innovation systems rather than as an outcome of an innovation system. That is, from a systems perspective, we claim that entrepreneurship should be looked upon as a function, similar to the way the traditional innovation systems literature treats organizations and institutions when considering functions that determine a systems ability to produce and exploit scientific discoveries and technological innovation.

\section{ENTREPRENEURIAL EXPERIMENTATION IN ENTREPRENEURIAL SYSTEMS OF INNOVATION}

\subsection{The need for entrepreneurial experimentation}

There are several challenges associated with commercialization of new ideas, products, and technologies. First, the actual distribution of returns in such ventures has a low median value but very high variance (Scherer and Harhoff 2000, Hall and Woodward 2010). Most new ventures and innovations fail badly, but some turn out to be highly successful. Second, even for professional investors or managers making resource allocation decisions, it is impossible to know in advance which ideas will work (Kerr et al 2014). There is genuine Knightian uncertainty (Knight 1921).

Entrepreneurial experimentation is a system-wide function that ensures creation, selection and scaling up (commercial exploitation) of new technologies and innovations. In an entrepreneurial system of innovation, individuals, organizations and institutions interact in the exploration, creation, discovery and exploitation of opportunities and new ideas. A system without exploration and creation of opportunities will form a poor basis for development and economic growth. Likewise, a system without commercial exploitation will not nearly live up to its full potential. In an entrepreneurial system of innovation, entrepreneurial experimentation is a key function for development of the system. Without experimentation the system will stagnate.

A key issue is that the system is effective in fulfilling all three activities, rather than separate individuals (researchers, entrepreneurs), organizations (research institutes, universities, small and large firms) and institutions (IP rights, incentive structures in the form of e.g. taxes and regulations, culture) being excellent in fulfilling only one or a few of the activities. In addition to organizations and institutions that have been stressed in the literature on innovation systems, individuals (e.g. inventors and entrepreneurs) - or individual agency - are of course central in entrepreneurial systems of innovation. However, this does not necessarily mean that it is individual entrepreneurs 
who create entrepreneurial opportunities. Instead, the creation of opportunities through technical experimentation (Lynn et al. 1996) is an important and indispensable part of an entrepreneurial system of innovation. Even if the creation of entrepreneurial opportunities is often not considered as part of the entrepreneurial process (e.g. Audretsch 1995, Shane 2003), it is the basis for entrepreneurial experimentation and the exploitation of opportunities in the system. Entrepreneurial experimentation is not only about whether opportunities exist, but in particular what is done about them and by whom (Acs et al 2014, Shane 2003, Shane and Venkataraman 2000).

In an entrepreneurial system of innovation, an individual entrepreneur might very well experiment with and exploit knowledge, technology or ideas created by someone else in the system. In an illustrative case study of one patented MIT-invention, Shane (2000) reports how this invention is licensed to eight different entrepreneurs, all experimenting with different types of market applications. Licensing and selling patents is one way of exploiting ideas commercially. However, the commercial exploitation and experimentation is not performed by the original inventor.

Entrepreneurship that feeds creation as well as selection requires an 'infrastructure' for entrepreneurship which includes the development of resource endowments for knowledge, technology, financing mechanisms, and competent labor, as well as an institutional governance structure that legitimizes and incentivizes entrepreneurship and individual action (Van de Ven 1993). An important dimension of an innovation system thus concerns its capacity to provide an efficient infrastructure for entrepreneurship that stimulates entrepreneurial experimentation in the system.

\subsection{Entrepreneurial experimentation through interaction between established firms, universities and new technology-based firms}

In what follows we outline how an infrastructure of established innovative firms and universities understood as sources of new knowledge, technologies and ideas - may in interaction with entrepreneurs who experiment with commercial applications by founding new technology-based firms stimulate the development of system-wide entrepreneurial experimentation that feeds innovation and growth. This provides an example of micro-level mechanisms and processes of industrial dynamics that, through actions of entrepreneurs and entrepreneurship, give rise to system-wide entrepreneurial experimentation that fosters creation, selection and scaling up of new technology and innovations.

\subsubsection{From established organizations to new technology and radical innovations - spinoffs}


Entrepreneurial experimentation is most often exemplified by new technology-based and innovative firms bringing novelties in the form of a technology, product or service to the market. While incumbents often seek to maximize the returns from known technology, rather than devote resources to entrepreneurial experimentation with an uncertain payoff, new entrants instead compete against established players by doing something different. Pioneering a technological innovation is the essence of doing something different: inventing around barriers to entry is a classic strategy by which new firms enter established markets (Hill and Rothaermel 2003). New entrants are unlikely to be able to circumvent the entry barriers that protect incumbents by pursuing incremental innovations, particularly given the capital resources that incumbents can devote to such innovations. Thus, as suggested by Hill and Rothaermel (2003), these different incentives will lead incumbents to drive forward with incremental innovations, whereas entrepreneurial new entrants will pioneer radical innovations.

Decades of research on entrepreneurship and industry dynamics shows that new companies are a heterogeneous group, with different survival and employment growth. Only a limited fraction of new firms qualify as innovation-driven Schumpeterian entrepreneurship (see, e.g. Mata et al 1995). Ex ante, there is of course substantial uncertainty as to the commercial potential of a radical technological innovation. Many seemingly promising innovations fail the test of market acceptance. It is not uncommon that a swarm of new technologies compete with each other as potential replacements for an established technology, with only one or two finally succeeding. A majority of new businesses survive only a short period and among the companies that survive, there are few that grow in terms of employment.

At the same time, research shows that the positive effects of entrepreneurship in an economy are largely attributable to the companies that survive for a long time, even if they are relatively few in number (Fritsch and Noseleit 2013, Lindholm-Dahlstrand and Billström 2014). Even if the majority of new entrants fail, new technologies often induce significant entry, and it only takes a handful of the 'entrepreneurial experiments' to be successful for a discontinuity to materialize (Utterback 1994). For a vibrant entrepreneurial experimentation, it is essential that a high number of new (technology-based) ventures are created. Also since new firms entering a market often encompass features that contribute to radical innovations (Henkel et al. 2015), new entrepreneurial firms play a critical role in the entrepreneurial experimentation.

This raises the question: from where do new technology-based and innovative new firms come? Thinking about this issue, it becomes clear that is hard to discuss Schumpeterian entrepreneurship in the form of new firms without recognizing established businesses and universities. In fact, a key argument in the knowledge spillover theory of entrepreneurship is precisely that entrepreneurial opportunities are created endogenously through $R \& D$ and other knowledge investments, typically in 
universities and in established firms (Acs et al 2009). Many of those opportunities are realized and tested on the market (commercial application) in the form of spinoffs from these types of organizations.

As a case in point, consider modern large technology-based firms, such as multinational corporations. They are typically multi-product, are involved in several technologies (or technology areas) and coupled service systems. Furthermore, they tend to have large intangible assets, a high fraction of knowledge workers with specialized advanced skills - i.e. a fine-grained internal division of labor - as well as large investments in $R \& D$ relative to sales (Andersson et al 2010). ${ }^{6}$ Thereby, they represent environments that are likely to raise the odds that employees and high-level managers are exposed to new knowledge and technologies that have a potential for commercial applications outside the firms' existing product or business areas. It is still common that a large firm does not encourage experimentation outside its technology, product or business areas. This implies that large R\&D and knowledge-intensive firms have an, often neglected, potential as sources of radical new innovations that are brought to the market through spinoff processes (Klepper and Thompson 2007, Andersson et al 2012). In other words, large firms can act as incubators for creation that feeds entrepreneurial experimentation. ${ }^{7}$ Entrepreneurship in the form of individual action (by employees), i.e. making a decision to leave a large firm to found a spinoff around new knowledge or technology, is still required to realize the full potential of large firms as sources of radical innovations and novelty.

Spinoffs have also been shown to outperform other types of new firms in several respects. For example, corporate spin-offs have superior post-entry performance in terms of both survival and employment growth compared to other types of new firms (Eriksson and Kuhn 2006, Andersson and Klepper 2013, Lindholm Dahlstrand 1997). This pattern is explained by that spin-offs inherit capabilities and routines from their parent organization, which gives them an advantage (Klepper 2001, Agarwal et al 2004). Compared to corporate spinoffs, university spinoffs tend to not show a similar performance premium (Wennberg et al 2011, Zahra et al 2007, Ensley and Hmieleski 2005).

However, studies comparing university and corporate spinoffs often neglect the long time-frame that often is needed to convert scientific research into commercially viable products and successful ventures. Lindholm Dahlstrand and Billström (2014) show that there are important time-lags before

\footnotetext{
${ }^{6}$ Markusen (1995, p. 172), for example, states that MNCs have four main characteristics: high R\&D relative to sales, a large share of professional and technical workers, products that are new and/or technically complex, and high levels of product differentiation and advertising.

${ }^{7}$ Similar lines of argument are also present in the so-called "anchor-tenant hypothesis" presented by Agrawal and Cockburn (2003). The idea is here that large R\&D-intensive firms help to develop an "innovation system" because mobility of individuals and other interactions with the external business environment feeds diffusion and spillovers of knowledge from the large firms to other parts of the economic system.
} 
university spinoffs starts to grow. One potential explanation of this is that university spinoffs are better equipped to contribute to disruptive radical innovation and transformative change. The role of university spinoffs in transformative change is not a well-researched topic, and there is a need for systematic empirical studies. There are a few empirical indications in the literature, for example in the German laser (Buenstorf 2007) and wind turbine industries (Bergek and Jacobsson 2003). Buenstorf's (2007) study of entrants seems to suggest that the academic spin-offs played a critical role in the early formative phases, while corporate spin-offs instead became important in the later phases. If these are general patterns or unique characteristics of only some industries is still an unexplored topic. Our reading of the available evidence suggest that corporate and university spin-offs play different but important roles in entrepreneurial experimentation. Even though the majority of technology-based new entrants are corporate spinoffs, university spinoffs appear to play a more important role for long-term renewal and transformative change.

The above line of argument suggests that entrepreneurship may be conceptualized as a function that feeds both creation and selection. New technology-based firms bring new technologies and knowledge to the market via commercial applications, and this means that they become subject to selection. The spinoff argument also suggests an important interplay between established organizations - firms as well as universities - and new technology-based firms. Spinoffs constitute a vehicle for spillovers of knowledge and technology from established organizations to the economic system.

\subsubsection{Acquisition and scaling up - complementarities and symbiosis between new innovative entrants and large established firms}

Another type of interplay between large established firms and new innovative entrants occurs in the process of selection and scaling up, in particular in high-tech and innovative industries. The mechanism we emphasize in this context is acquisitions. Specifically, acquisition is one means by which a 'symbiosis' between new technology-based and innovative entrants and large established businesses is realized - it is both a selection mechanism where 'good' new firms are selected as acquisition targets as well as a mechanism that may feed scaling up (Andersson and Xiao 2016, Xiao 2015). To derive this argument, we start by discussing the incentives facing the founders of new firms to be acquired (or to sell) and then go on to discuss the incentives facing the acquiring firms.

From the perspective of start-ups, there are several arguments concerning the incentives that new entrepreneurs have to opt for a commercialization strategy that involves selling the business to an incumbent firm. The main one is that the costs of fully exploiting the commercial potential associated with a new technology or innovation are often high. Gans and Stern (2003) maintain that the commercialization strategy for start-up innovators "... often presents a tradeoff between establishing a 
novel value chain and competing against established firms versus leveraging an existing value chain and earning returns through the market for ideas" (ibid p. 335). In other words, when the costs of and need for complementary resources to build a novel value chain and expand on international markets are high, commercialization through the market for corporate control is a viable option for start-ups. Norbäck and Persson (2014) build a game theoretic model to analyze entry strategies of entrepreneurs building their business on a new technology. Similar to the argument by Gans and Stern (2003), their model lets entrepreneurs have two options when it comes to commercialization: (i) entering the world market or (ii) selling the business to incumbents. They then show that, under plausible assumptions, the second option is more favorable when incumbents have high market power and when entrants' costs of going global independently are high. These predictions are consistent with the empirical finding that acquisitions of new technology-based firms tend to be more frequent in high-technology and innovative industries (Andersson and Xiao 2016). In a survey analysis of technology-based new firms in Sweden, Lindholm (1996) also shows that the ambition to expand or internationalize their businesses was the second most important reason for owners of new technology-based firms to sell.

The literature further points out that a specific hurdle that may steer entrepreneurs towards a strategy to sell their business by being acquired concerns financial resources. Compared to large and established firms, small and young firms access to capital markets is limited (Himmelberg and Petersen 1994), and difficulties in gaining access to external financing is a main factor preventing small new firms from fully exploiting their commercial potential (Carpenter and Petersen 2002ab, Colombo and Grilli 2005, 2007). In fact, if venture capital markets are weak and an initial public offering (IPO) unfeasible, then being acquired is one of the few available options to secure financing and continue exploiting the technology or product idea that the start- up is based on (Andersson and Xiao 2016). ${ }^{8}$ Being acquired by a financially strong incumbent is under these circumstances a way to secure finance (Utterback et al 1988, Graebner and Eisenhardt 2004). Lindholm's (1996) survey analysis also confirms that founders of new technology-based firms cite lack of financial capital as a major motive for selling their businesses.

Turning to the motives of the acquiring firm, it is of course the case that there are many types of motives for acquisitions. These include (Andersson and Xiao 2016):

- achieving market power

- technology sourcing

- $\quad$ synergy gains

\footnotetext{
${ }^{8}$ Partly consistent with this, Xiao (2015) studies the effect that being acquired has on new technology-based firms in Sweden and find that being acquired by Swedish MNEs significantly improves employment growth in employment among new technology-based firms.
} 
- lowering transaction costs

- corporate control

Still, it is clear that, in particular in high-technology and innovative industries, acquisitions involving recent technology-based and innovative start-ups tend to be motivated by a strategy to acquire technology and innovations that can be embedded into and/or expand the acquirer's businesses and strengthen its technological capabilities (Granstrand and Sjölander 1990, Desyllas and Hughes 2008). Acquistions can thus be seen as one form of technology and knowledge transfer process made possible through the market for corporate control.

In fact, it has been suggested in the innovation management literature that, instead of spending valuable resources and managerial talent on growing new radical businesses inside established firms, incumbent firms may instead have as a strategy to facilitate the creation of a network of young, entrepreneurial firms, so-called 'feeder firms', that are busy colonizing new niches (Markides 2006). Should such firms turn successful, the established firms can use their complementary resources that enable them either to enter alliances with the new entrants or to acquire the new entrants on favorable terms, thereby enhancing their position (Hill and Rothaermel 2003).

Incumbents could also serve as minority investors or as venture capitalists to entrepreneurial firms. For new entrants engaged in radical technological innovation, long gestation periods strain capital resources, increasing the probability that the firms will exhaust their capital resources before they have successfully marketed new products. Then, when the market starts to consolidate, the large incumbents could build a new mass-market business on the platform these feeder firms have provided (Markides 2006). Since the younger firms do not have the resources, power, marketing, and distribution to scale up their creations, this could be 'subcontracted' to larger firms; or by being acquired.

This type of reasoning is concordant to Williamson's (1975) discussion of a 'systems approach' and in particular his proposition of a 'systems solution by classical specialization'. Even though Williamson introduced what he called the 'systems solution' over forty years ago, the idea is still quite unexplored in innovation systems contexts. Williamson's argument in brief is that small firms are frequently high performers when it comes to product innovation. Furthermore, small firms often have advantages in the early stages of the innovation process, as well as in less expensive and radical innovations, while large firms have an advantage in the later stages of scaling up innovations. In other words, large scale, or size, is often claimed to be a determinant of malfunction in the earlier and creative stages of the innovation process. Therefore, as Williamson (1975) proposed, the 'systems solution by classical specialization' may be an efficient innovation process. These ideas are conceptually rather close to the argument that there is a 'symbiosis' between new and small technology-based and innovative entrants 
and established large firms, that foster scaling up, and that acquisition is an important mechanism by which such a symbiosis is realized.

In his hypothesis of a symbiosis between large and small firms, Baumol (2002) argues that small innovative firms have complementary roles in the system-wide innovation process, because they have their respective advantages at different stages of the innovation process. Small innovative firms often account for more radical innovations and new technology. Audretsch (1995) shows for example that many radical innovations and technologies are introduced by new and young technology-based firms. In contrast, since large firms can spread costs of innovation over larger production volumes, they have stronger incentives for less radical process innovations (Klepper 1996). However, as argued above, even if new innovative entrants bring more radical innovations to the market, they often lack resources to scale up, refine, and extend them. Larger established firms have complementary capabilities and resources in the form of knowledge, finances as well as an 'infrastructure' of global sales networks. They are thus in a better position to enhance or embed the novelties developed by the small entrants into existing products and production processes. Based on their knowledge of the market, their economies of scale and accumulated experiences, they are able to refine the technologies and use their established market channels to exploit innovations on the global market.

The emphasis on global markets is important because it illustrates why founders (or owners) of new technology-based firms may be particularly willing to create networks to multinational corporations, perhaps with the intention to be acquired. Internationalization and outreach to foreign markets is of course important to fully exploit the commercial potential of new technology and innovations. Multinational corporations that have global sales and production platforms may therefore have greater willingness to pay for an innovation brought to the market than other potential acquirers; provided that the multinational can use already established platforms to leverage the innovation. ${ }^{9}$ Entrepreneurs could therefore purposefully strive to sell their business to multinationals because it is a more rewarding commercialization strategy, compensating their entrepreneurial activities and expertise (Bonardo et al. 2010, Meoli et al 2013).

This reinforces the argument of mutually beneficial interaction between typically large global firms and new technology-based firms. To the extent that network formation and contacts between new entrepreneurs and multinationals are facilitated by proximity, it also provides tentative arguments why the presence of multinationals in a country, region or city may be beneficial; not only for commercial

\footnotetext{
${ }^{9}$ One could potentially regard existing sales networks and global production systems of MNCs as a kind of platform which can be used to produce, distribute and market many kinds of related products and/or services. Therefore, MNCs may have higher willingness to pay to get hold of a new innovation, e.g. through acquisition, because they are able to exploit it in large volumes using their existing platforms. The interaction between new firms in biotechnology and large established MNCs in classic pharmaceuticals industry is a good example.
} 
exploitation and scaling up of innovations and new technologies brought to the market by new entrants, but also for the potential return that entrepreneurs can get when selling their firm as a commercialization strategy. ${ }^{10}$

The symbiosis often takes the form of partnerships between the firms, or through incumbents acquiring the new technology-intensive firms (Lindholm 1996). For technology-intensive young companies, collaboration with established large companies may be needed to bring up sales volumes and penetrate major international markets. ${ }^{11}$ This brings us back to Williamson's (1975) suggestion that, because of the small firms' innovation advantages in the early stages, an efficient procedure by which to introduce new products would be to allow the initial stages of the innovation process to be performed by independent innovators and small firms. The successful companies would then be acquired for subsequent development by a large firm. This suggests that acquisitions constitute one way in which the symbiosis can be realized, because it could mean that the acquiring large firm enhances continued technology development and broadens experimentation, or simply provide financial resources to continue working on the innovation. It is in other words a mechanism for scaling up.

\subsubsection{Summary of the argument - entrepreneurial experimentation through creation, selection and scaling up}

Figure 1 provides a schematic picture of the process described above. It aims to summarize our arguments suggesting that spinoffs and acquisitions are examples of micro-mechanisms and processes of industrial dynamics that articulate how the behavior of entrepreneurs and entrepreneurship gives rise to system-wide entrepreneurial experimentation that fosters creation, selection and scaling up of new technology and innovations. It portrays established firms and universities as sources of the creation of new technologies and knowledge and spinoffs as an entrepreneurial function that connects creation and selection. Spinoffs bring innovations to the market and make them subject to selection. Acquisition is a function that bears on both selection and scaling up.

It should be noted that the perspective outlined in Figure 1 suggests that the classic question in innovation studies, as well as in the Schumpeterian industrial dynamics literature, of whether small or large firms matter the most in innovation is misleading. Instead, the perspective here suggests that they

\footnotetext{
${ }^{10}$ Such an argument applies in particular to countries with small domestic markets (such as Sweden, Denmark, Switzerland) in industrial contexts where the costs of going abroad independently are high.

${ }^{11}$ In a similar fashion, Henkel et al (2015) suggest that the existence of a market for technology between entrants and incumbents drives the former to pursue radical innovations. Entrepreneurial experimentation among entrants results in many new firms, which in parallel try to develop innovative solutions to different needs. They also show that in situations where complementary resources of incumbents are necessary for a firm to succeed, the new entrants generally need to be acquired to survive in the long run.
} 
fill complementary roles in innovation and that they operate in interplay in an entrepreneurial system of innovation.

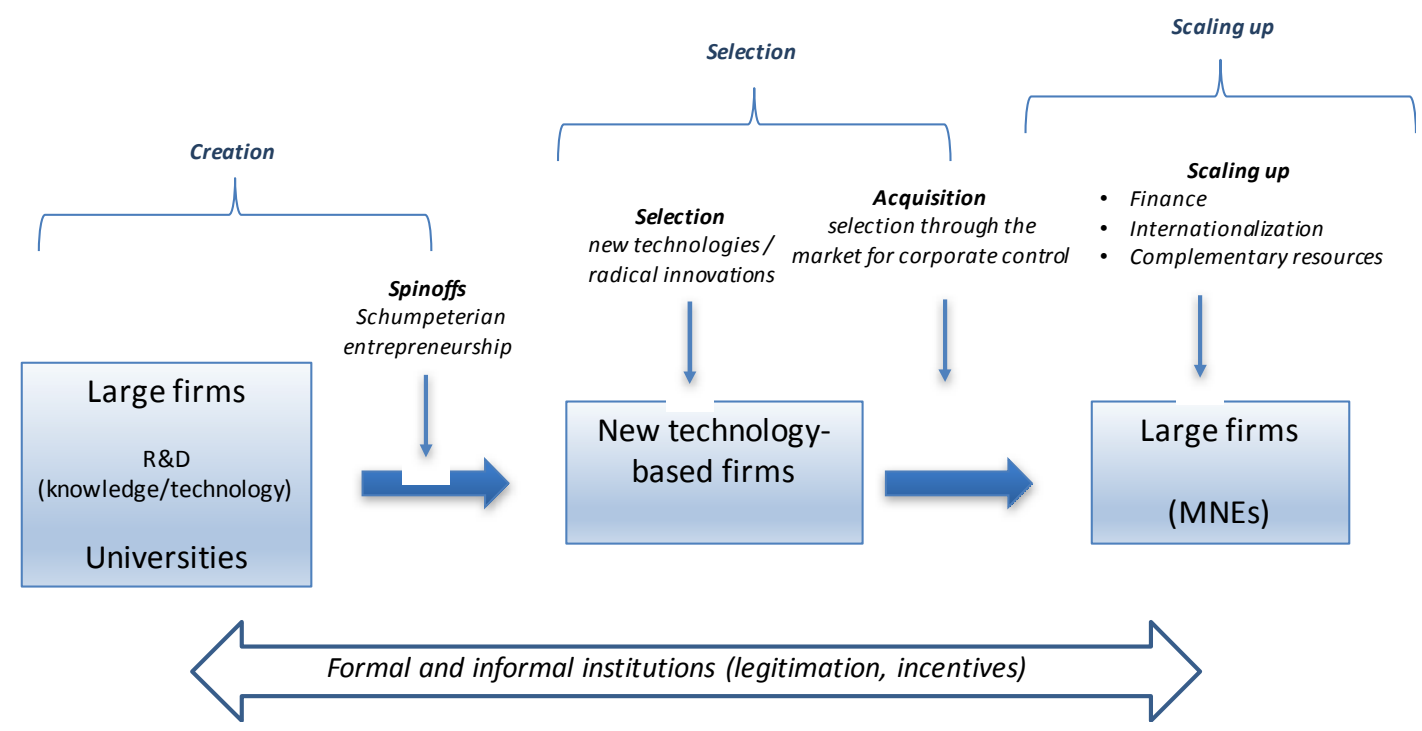

Figure 1. Creation, selection and scaling up through spinoffs and acquisitions - an example of system-wide entrepreneurial experimentation.

Our arguments are supportive to Haltiwanger's et al (2013) concluding conjecture which they base on an empirical analysis of the respective role of "small versus large versus young" firms in creating jobs in the United States. They write:

"It may be, for example, that the volatility and apparent experimentation of young businesses that we have identified is critical for the development of new products and processes that are in turn used by (and perhaps acquired by) the large and mature businesses that account for most economic activity" (ibid p. 361).

In particular, our arguments are meant to illustrate that an entrepreneurial system where large and new firms interact through technology-related ownership changes, under certain conditions, can be highly conducive to innovativeness and growth.

Figure 2 summarizes, in a stylized way, the arguments about the respective advantage of established large firms and new innovative and technology-based firms in an economic system, where '+' and '-. reflect advantages and disadvantages, respectively. 

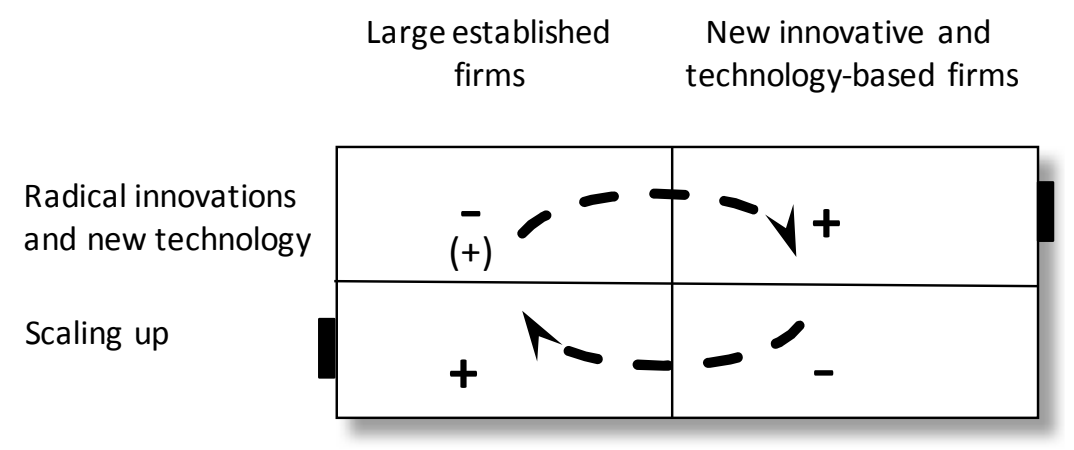

Figure 2. The changing respective advantages of large established firms and new innovative and technology-based firms in various 'stages' of the innovation and commercialization process.

In line with Baumol's (2002), large firms may be sources of new technologies, knowledge and ideas, but new innovative and technology-based firms are in a better position to bring radical innovations and new technology to the market. Entrepreneurship in the form of spinoffs could be conceived of as a system-wide function that reflects a 'systems solution by classical specialization' (Williamson 1975), where new entrants bring radical innovations and new technology to the market.

In the phase of scaling up, the advantage shifts from the new entrants back to large established firms that have complementary resources. Here, acquisitions could be interpreted as a 'systems solution by classical specialization' reflecting the fact that the established large firms have pertinent complementary resources and capabilities. Acquisitions may in turn spur further spinoffs, for example due to disagreements between managers and high-level workers following acquisitions (see e.g. Thompson and Chen 2011, Klepper and Thompson 2010).

Before turning to conclusions, three remarks are in order to put our arguments in context. First, although our focus is not on institutions or policy, we recognize that entrepreneurial experimentation is influenced by formal as well as informal institutions. For example, for spinoffs to happen there needs to be an institutional framework that provides incentives for individual action and fosters labor market mobility. In fact, one may argue that a crucial feature of an innovation system is to provide incentives for individuals to engage in entrepreneurship and exploit opportunities (Braunerhjelm and Henrekson 2016). ${ }^{12}$

\footnotetext{
${ }^{12}$ The importance of the mechanisms may also be dependent on institutions and the surrounding infrastructure (broadly defined). For example, as argued previously, one reason why founders of new firms may be willing to be acquired (or to sell the firm) is that they lack financial resources to scale up and refine their technology, product or service. Such a lack of financial resources could in turn depend on an institutional context that suppress the development of a well-functioning venture capital market (see e.g. Lerner and Tåg 2013). An argument can thus be made that acquisitions may be a less important mechanism for scaling up when institutional contexts are such that venture capital markets function well.
} 
Second, our focus on spinoffs and acquisitions does not mean that genuinely de novo firms are unimportant and that acquisitions are a pre-requisite for scaling up. We emphasize that we use spinoffs and acquisitions as examples of micro-mechanisms and processes of industrial dynamics to illustrate how entrepreneurship gives rise to system-wide entrepreneurial experimentation that fosters creation, selection and scaling up of new technology and innovations. At the same time, both spinoffs and acquisitions are indeed central mechanisms in many high-tech and knowledge-intensive industries where innovations play a key role, such as biotechnology, electronics and other high-tech engineering industries. Spinoffs have also been shown to play an important role in the evolution of new industries, particularly in early stages where innovation and experimentation is important (US automobile industry, Klepper 2002; laser industry, Klepper and Sleeper 2005; semiconductors, Malone 1985; disk drive industry Agarwal et al., 2004). Furthermore, Andersson and Xiao (2016) study acquisitions of new firms and find evidence that acquisitions of new firms primarily involve new technology-based firms that operate in high-tech and innovative industries characterized by sizeable costs of scaling up, and when incumbents (typically MNEs) have significant market power and complementary assets and capabilities.

Third, our discussion has not addressed the question of system boundaries. This is deliberate since our focus is on articulating the function of entrepreneurial experimentation. However, similar to the literature on technological innovation systems (Carlsson and Stankiewicz 1991), our framework suggests that there are multiple system boundaries. For example, the spinoff process may be placespecific in the sense that spinoffs tend to locate close to their parent organizations, and founders are likely to be influenced by the local institutions in the form of attitudes, entrepreneurship culture and regulations (Carias and Klepper 2010, Andersson and Henrekson 2015, Westlund et al 2014, Andersson and Larsson 2016). The local scale may also matter extensively when it comes to availability of skilled workers and other types of supply-side resources (Glaeser 2007). Therefore, the relevant boundary may be a high-tech cluster, like Silicon Valley, or a city like Stockholm, London or Seattle. For selection and scaling up, however, the relevant scale may instead be global, and ultimately dependent on the location of major established firms and MNCs, as well as the overall (global) organization of the relevant industry or technology area. This suggests that the various mechanisms may pertain to different primary boundaries, and the boundaries are likely to change as the organization and location pattern of industries and large established firms evolve.

\section{SUMMARY AND CONCLUDING REMARKS}

An institutional environment that facilitates experimentation is central to maintaining a vibrant entrepreneurial system of innovation. We argue in this paper that the central function of 
entrepreneurial experimentation in innovation systems is the creation, selection and scaling-up of innovations. Entrepreneurial experimentation relates both to the "supply-side", in terms of the system's capacity to develop a variety of new technologies and business ideas that become subject to selection (technical experimentation), as well as to the "demand-side", in terms of the efficiency of selection and scaling up of innovations and businesses on the market (market experimentation). We also argue that both technical and market experimentation are critical for the development of an Entrepreneurial System of Innovation. Both forms of experimentation, combined with a willingness to let losing incumbents fail, may in fact be argued to constitute the underlying notion behind Schumpeter's (1942) process of "creative destruction". The rate of entrepreneurial experimentation has implications for what types of innovations will occur, who will pursue them and when. As Stern (2005) argued, "a favorable environment for entrepreneurship and a high level of economic experimentation go hand in hand". Although experiments can be conducted in large companies or in the public sector, new technologies and innovative products are often commercialized by entrepreneurs and often cluster at particular times.

Reviewing the extant literature on innovation systems, it is our conclusion that it does not yet articulate the function of entrepreneurs and entrepreneurship. In particular, what is lacking is an analytical framework that, with reference to explicit micro-level mechanisms and processes of industrial dynamics, articulates how the actions of entrepreneurs and entrepreneurship give rise to system-wide entrepreneurial experimentation that fosters creation, selection and scaling up of new technology and innovations.

This paper claims that filling this gap in the literature requires (i) a recognition that entrepreneurial experimentation comprises both 'technical' and 'market' experimentation, (ii) that entrepreneurship is analytically conceptualized in terms of its function in innovation systems rather than as an outcome of an innovation system. That is, from a systems perspective, we claim that entrepreneurship should be looked upon as a function, similar to the way the traditional innovation systems literature treats organizations and institutions when considering functions that determine a system's ability to produce and exploit scientific discoveries and technological innovation.

To make a step towards the development of a framework that accommodates these requirements, we identified two mechanisms for the entrepreneurial experimentation in the system: spinoffs and acquisitions. Both are micro-based and relate directly to processes of industrial dynamics. We make a strong case that the spin-off mechanism is critical for the creation of high-quality new firms, and that the acquisition mechanism is important for the scaling up of exploitation activities in such firms. Building on particular on Baumol's (2002) conjecture of a symbiosis between new entrants and established firms, we argue that new firms and established incumbents have different advantages and 
disadvantages in entrepreneurial experimentation, and that they, in interaction with each other through spinoffs and acquisitions, fulfil different roles in entrepreneurial systems of innovation. Our argument is that an entrepreneurial system of innovation where large and new firms interact through spinoffs and technology-related ownership changes, under certain conditions, can be highly conducive to innovativeness and growth.

Although our main focus is not on policy, the framework suggests that policy must consider both technical and market experimentation, which means that a careful consideration of the broader institutional framework is necessary. The experimentation view also suggests that there may be systematic market failures when the costs associated with experimentation are too high or the returns are too uncertain and far into the future. This means that the institutional framework needs to support or facilitate long-term perspectives.

On a general level, an infrastructure of organizations that invest in new knowledge and technology combined with an institutional governance system that feeds interaction between incumbents and new firms, and provides incentives of individual action is critical for the functioning of the entrepreneurial system of innovation. For example, for spinoffs to happen there needs to be an institutional framework that provides incentives for individual action and fosters labor market mobility. In fact, one may argue that a crucial feature of an innovation system is to provide incentives for individuals to engage in entrepreneurship and exploit opportunities (Braunerhjelm and Henrekson 2016).

Our framework reinforces the argument of Kerr et al (2014), i.e. that constraints on the ability of entrepreneurs and investors to experiment effectively can shape which industries, organizations, and time periods see the most radical innovations. It also sets the framework for understanding where barriers to experimentation may lead to market failures. When the time horizon for commercialization is extremely uncertain and distant, such as in the case of basic research, institutional regimes may be critical to enable experimentation in areas that are of importance to society but where a process of serial entrepreneurial experimentation by profit-seeking investors is unlikely to provide a set of stepping-stones to the technologies behind disruptive innovation (Kerr et al 2014).

Being mainly conceptual, the framework in this paper would need to be complemented and supported by further empirical research. In an Entrepreneurial system of innovation, we suggest empirical studies of the spin-off and acquisition mechanisms. Important research questions to be considered are:

- What are the different roles of entrepreneurial experimentation in transformative change?

- Are the roles different in different sectors and at different points in time?

- If so, why are they different? And to what effect? 
Analyzing these questions includes studying the roles that ownership changes (acquisitions and different kinds of spin-offs) in different technological sectors over long time periods. It should also be considered that systems change over time, and that formative phases might be substantially different from phases of expansion or stagnation. This in turn is likely to have important policy implications.

\section{REFERENCES}

Acs, Z. J., Autio, E., and Szerb, L., (2014). National systems of entrepreneurship: Measurement issues and policy implications. Research Policy, 43(3), 476-494.

Acs, Z., Braunerhjelm, P., Audretsch, D. and Carlsson, B., (2009). The knowledge spillover theory of entrepreneurship, Small Business Economics, 32(1), 15-30

Agarwal, R. Raj, E., Franco and Sarkar, MB., (2004). Knowledge transfer trough inheritance: Spinout generation, development and survival, Academy of Management Journal, vol 47 (4), 501-522

Agrawal, A., and I Cockburn., (2003), "The Anchor-Tenant Hypothesis - exploring the role of large, local, R\&D-intensive firms in regional innovation systems", International Journal of Industrial Organization, 21, 1227-1253.

Andersson, M., and Henrekson, M., (2015). Local Competitiveness Fostered through Local Institutions for Entrepreneurship in Audretsch, D., Link, A.N. and Walshok, M. (eds), Oxford Handbook of Local Competitiveness, Oxford, Oxford University Press

Andersson, M., and Xiao, J., (2014). Acquisition of Start-Ups by Incumbent Businesses - a market selection process of high-quality entrants?, Research Policy, 45 (1), 272-290

Andersson, M., and Klepper, S., (2013) Characteristics and performance of new firms and spinoffs in Sweden, Industrial and Corporate Change, Volume 22, Number 1, pp. 245-280

Andersson, M., and Larsson, J.P., (2016). Local Entrepreneurship Clusters in Cities. Journal of Economic Geography, 16 (1), 39-66

Andersson, M., Baltzopoulos, A. and Lööf, H., (2012). R\&D Strategies and Entrepreneurial Spawning, Research Policy, 41 (1), 54-68

Andersson, M., Johansson, B., Karlsson, K., and Lööf, H., (2010). Multinationals in the Knowledge Economy - a case study of Astra Zeneca in Sweden, in Karlsson, C and Bohne, E (Eds) (2010). Repositioning Europe and America for Growth - the role of governments and private actors in key policy areas, Berlin, LIT Verlagan

Audretsch, D. B. (1995) Innovation and Industry Evolution. Cambridge, MA: MIT Press.

Baumol, W. J. (2002). Entrepreneurship, innovation and growth: The David-Goliath symbiosis. Journal of Entrepreneurial Finance, JEF, 7(2), 1-10. 
Bergek, A., Jacobsson, S., (2003). The emergence of a growth industry: a comparative analysis of the German, Dutch and Swedish wind turbine industries. in Metcalfe, S., Cantner, U. (Eds.), Change, Transformation and Development. Physica-Verlag, Heidelberg, pp. 197-227.

Bergek, A., Jacobsson, S., Carlsson, B., Lindmark, S., and Rickne, A., (2008). Analyzing the functional dynamics of technological innovation systems: A scheme of analysis. Research policy, 37(3), 407-429.

Bonardo, D., Paleari, S., and Vismara, S., (2010). The M\&A dynamics of European science-based entrepreneurial firms. The Journal of Technology Transfer, 35(1), 141-180.

Braunerhjelm, P., and Henrekson, M., (2016) An Innovation Policy Framework: Bridging the Gap between Industrial Dynamics and Growth, in Audretsch, D. and Link, A. (Eds) (2016). Essays in Public Sector Entrepreneurship, Berlin, Springer

Braunerhjelm, P., Acs, Z., Audretsch, D., and Carlsson, B., (2010). The missing link: knowledge diffusion and entrepreneurship in endogenous growth, Small Business Economics, 34(2), 105-12

Breschi, S., and Malerba, F., (1997) Sectoral innovation systems, in Edquist C. Ed. Systems of Innovation: Technologies, Institutions and Organisations, London:Pinter.

Buenstorf, G., (2007). Evolution on the shoulders of giants: Entrepreneurship and firm survival in the German laser industry. Review of Industrial Organization, 30(3), 179-202.

Carias, C., and Klepper, S., (2010). Entrepreneurship, the initial labor force and the location of new firms. International Schumpeter Society Conference 2010, Aalborg, Denmark

Carlsson, B., (2006). Internationalization of innovation systems: A survey of the literature. Research Policy, 35(1), 56-67.

Carlsson, B., and Jacobsson, S., (1997) Diversity creation and technological systems: a technology policy perspective, in Edquist C. (eds), Systems of Innovation: Technologies, Institutions and Organisations, London: Pinter.

Carlsson, B., Acs, Z. J., Audretsch, D. B., and Braunerhjelm, P., (2009). Knowledge creation, entrepreneurship, and economic growth: a historical review. Industrial and Corporate Change, 18(6), 1193-1229.

Carlsson, B., and Eliasson, G., (2003). Industrial dynamics and endogenous growth. Industry and innovation, 10(4), 435-455

Carlsson, B., Stankiewicz, R., (1991) On the nature, function, and composition of technological systems. Journal of Evolutionary Economics 1, 93-118.

Carpenter, R. E., and Petersen, B.C., (2002a). Capital market imperfections, high-tech investment, and new equity financing. The Economic Journal, 112(477), F54-F72.

Carpenter, R. E., and Petersen, B.C., (2002b). Is the growth of small firms constrained by internal finance? The Review of Economics and Statistics, 84(2), 298-309.

Colombo, M. G., and Grilli, L., (2005). Start-up size: The role of external financing. Economics Letters, 88(2), 243-250. 
Colombo, M. G., and Grilli, L., (2007). Funding gaps? Access to bank loans by high-tech start-ups. Small Business Economics, 29(1-2), 25-46.

Cooke, P., (1996) Regional innovation systems: an evolutionary approach. In Baraczyk, H., Cooke, P. and Heidenriech, R. (eds), Regional Innovation Systems, London: London University Press.

Desyllas, P., and Hughes, A., (2008). Sourcing technological knowledge through corporate acquisition: Evidence from an international sample of high technology firms. The Journal of High Technology Management Research, 18(2), 157-172.

Edquist, C., (ed.) (1997) Systems of Innovation: Technologies, Institutions and Organizations. London: Pinter.

Ensley, M. D., and Hmieleski, K.A., (2005). A comparative study of new venture top management team composition, dynamics and performance between university-based and independent start-ups. Research Policy, 34(7), 1091-1105.

Eriksson, T., and Kuhn, J.M., (2006). Firm spin-offs in Denmark 1981-2000: Patterns of entry and exit., International Journal of Industrial Organization, 24(5), 1021-1040.

Freeman, C., (2002) Continental, national and sub-national innovation systems, Research Policy, $31: 191-211$.

Freeman, C., (1987). Technology Policy and Economic Performance. Pinter Publishers, London.

Freeman, C., and Soete, L., (Eds.). (1997). The economics of industrial innovation. Psychology Press.

Fritsch, M., and Noseleit, F., (2013). Start-ups, long-and short-term survivors, and their contribution to employment growth. Journal of Evolutionary Economics, 23(4), 719-733.

Gans, J. S., and Stern, S., (2003). The product market and the market for "ideas": Commercialization strategies for technology entrepreneurs. Research Policy, 32(2), 333-350.

Garud, R., and Karnøe, P., (2003). Bricolage versus breakthrough: distributed and embedded agency in technology entrepreneurship. Research policy, 32(2), 277-300.

Glaeser, E., (2007). Entrepreneurship and the city. National Bureau of Economic Research Working Paper No. 13551

Graebner, M. E., and Eisenhardt, K. M., (2004). The seller's side of the story: Acquisition as courtship and governance as syndicate in entrepreneurial firms. Administrative Science Quarterly, 49(3), 366-403.

Granstrand, O., and Sjölander, S., (1990). The acquisition of technology and small firms by large firms. Journal of Economic Behavior and Organization, 13(3), 367-386.

Hall, R. E., and. Woodward, S.E., (2010) The Burden of the Nondiversifiable Risk of Entrepreneurship, American Economic Review 100(3): 1163-94.

Haltiwanger, J., Jarmin, R. S., and Miranda, J., (2013). Who creates jobs? Small versus large versus young, Review of Economics and Statistics, 95(2), 347-361 
Hekkert, M.P., Suurs, R.A.A., Negro, S.O., Smits, R.E.H.M., and Kuhlmann, S., (2007). Functions of innovation systems: a new approach for analyzing technological change. Technological Forecasting and Social Change 74, 413-432.

Henkel, J., Rønde, T., and Wagner, M., (2015). And the winner is-Acquired. Entrepreneurship as a contest yielding radical innovations. Research Policy, 44(2), 295-310.

Hill, C. W., and Rothaermel, F. T., (2003). The performance of incumbent firms in the face of radical technological innovation. Academy of Management Review, 28(2), 257-274.

Jacobsson, S., and Bergek, A., (2004) Transforming the energy sector: The evolution of technological systems in renewable energy technology, Industrial and Corporate Change 13, 815-849.

Johnson, A., and Jacobsson, S., ( 2001) Inducement and blocking mechanisms in the development of a new industry: the case of renewable energy technology in Sweden. In: Coombs, R., Green, K., Walsh,V., Richards, A. (Eds.),Technology and the Market: Demand, Users and Innovation. Edward Elgar, Cheltenham.

Kemp, R., Schot, J., and Hoogma, R., (1998). Regime shifts to sustainability through processes of niche formation: the approach of strategic niche management. Technology Analysis and Strategic Management, 10, 175-195.

Kerr, W. R., Nanda, R., and Rhodes-Kropf, M., (2014) Entrepreneurship as Experimentation, Journal of Economic Perspectives, 28(3), 25-48

Klepper, S., (1996). Entry, Exit, Growth, and Innovation over the Product Life Cycle, American Economic Review, 86(3), 562-583,

Klepper, S., and Thompson, P., (2010). Disagreements and intra-industry spinoffs, International Journal of Industrial Organization, 28(5), 526-538

Klepper, S., (2001). Employee startups in high-tech industries. Industrial and Corporate Change, 10, 639-674

Klepper, S., (2002). The capabilities of new firms and the evolution of the US automobile industry. Industrial and Corporate Change, 11, 645-666.

Klepper, S., (2016). Experimental Capitalism: the Nanoeconomics of American High-Tech Industries, Princeton, Princeton University Press

Klepper, S., and Sleeper, S., (2005). Entry by spinoffs. Management Science, 51, 1291-1306

Klepper, S., and Thompson, P., (2007). Spinoff Entry in High-tech Industries: motives and consequences, in Malerba, F and Brusoni, S (Eds.), Perspectives on Innovation. Cambridge, Cambridge University Press

Knight, F. H. (1921). Risk, Uncertainty, and Profit. Boston MA, Houghton Mifflin Company

Landström, H., Harirchi, G., and Åström, F., (2012). Entrepreneurship: Exploring the knowledge base. Research Policy, 41(7), 1154-1181.

Lerner, J., and Tåg, J., (2013). Institutions and venture capital. Industrial and Corporate Change, 22(1), 153-182 
Lindholm Dahlstrand, Å., (2009) Innovative Entrepreneurship: Commercialization by Linking Ideas and People, in Marklund, G., Vonortas, N., and Wessner, C., and (Eds) The Innovation Imperative - National Innovation Strategies in the Global Economy, Edvard Elgar

Lindholm Dahlstrand, Å., and Billström, A., (2014) Corporate and University Spin-Offs: A study of long-term performance, Working Paper, Working paper, paper presented at Entreprenörskapsforum, May 17-18, 2013, Lund, Sweden..

Lindholm Dahlstrand, Å., (1997). Growth and Innovativeness in Technology-based Spin-off Firms, Research Policy, 26, 331-344

Lindholm Dahlstrand, Å., (1999). Technology-based SMEs in the Göteborg Region: Their Origin and Interaction with Universities and Large Firms. Regional Studies, 33(4), 379-389

Lindholm, A., (1996). An economic system of technology-related acquisitions and spin-offs. University of Cambridge, ESRC Centre for business research.

Lundvall, B., (1999). National Business Systems and National Systems of Innovation. International Studies of Management \& Organization, 29(2), 60-77

Lundvall, B.-Å., (1985). Product Innovation and User-Producer Interaction, Aalborg: Aalborg University Press.

Lundvall, B.-Å., (Ed) (1992). National Systems of Innovation: Towards a Theory of Innovation and Interactive Learning, London:Pinter.

Lynn, G., Morone, J. G., and Paulson, AS,. (1996). Marketing and discontinuous innovation: the probe and learn process. California management review, 38(3)

Malerba, F., (2002). Sectoral systems of innovation and production. Research Policy 31, 247-264.

Malerba, F., (2004). Sectoral systems of innovation: basic concepts. in Malerba, F. (Ed.), Sectoral Systems of Innovation: Concepts, Issues and Analysis of Six Major Sectors in Europe. Cambridge University Press.

Malone, M., (1985). The Big Score: The Billion Dollar Story of Silicon Valley. Garden City NJ, Doubleday

Markard, J., and Truffer, B., (2008). Technological innovation systems and the multi-level perspective: Towards an integrated framework. Research policy, 37(4), 596-615.

Markides, C., (2006). Disruptive innovation: In need of better theory*. Journal of product innovation management, 23(1), 19-25.

Markusen, J.R., (1995). The Boundaries of Multinational Enterprises and the Theory of International Trade, Journal of Economic Perspectives, 9(2), 169-189

Maskell, P., and Malmberg, A., (1999) Localised learning and industrial competitiveness, Cambridge Journal of Economics, 23 (2):167-186.

Mason, C., and Brown, R., (2014). Entrepreneurial Ecosystems and Growth-Oriented Enterprises: Background Paper Prepared for the Workshop Organised by the OECD LEED Programme and the Dutch Ministry of Economic Affairs. 
Mata, J., Portugal, P., and Guimaraes, P., (1995), The Survival of New Plants: start-up conditions and post-entry survival, International Journal of Industrial Organization, 13, 459-481

Meoli, M., Paleari, S., and Vismara, S., (2013). Completing the technology transfer process: M\&As of science-based IPOs. Small Business Economics, 40(2), 227-248

Moore, G., and David, K., (2004). Learning the Silicon Valley way, in Bresnahan, T. And Gambardella, A. (Eds) (2004), Building High-Tech Clusters - Silicon Valley and beyond, Cambridge, Cambridge University Press

Nelson, R., (Ed.) (1993). National Innovation Systems: A Comparative Study. Oxford University Press, Oxford.

Nelson, R., (1987). Capitalism as an engine of progress. Working Paper, Columbia University, New York.

Norbäck, P.-J., and Persson, L., (2014). Born to be global and the globalisation process. The World Economy, 37(5), 672-689

North, D.C., (1990). Institutions, Institutional Change, and Economi Performance. Cambridge University Press, Cambridge, UK.

Qian, H., Acs, Z. J., and Stough, R. R., (2012). Regional systems of entrepreneurship: the nexus of human capital, knowledge and new firm formation. Journal of Economic Geography, lbs009.

Radosevic, S., and Yoruk, E., (2013). Entrepreneurial propensity of innovation systems: Theory, methodology and evidence. Research Policy, 42(5), 1015-1038.

Rosenberg, N., (1994). Exploring the black box: Technology, economics, and history. Cambridge University Press.

Santarelli, E., and Vivarelli, M., (2007). Entrepreneurship and the process of firms' entry, survival and growth. Industrial and Corporate Change, 16(3), 455-488.

Scherer, F. M., and Harhoff, D., (2000) Technology Policy for a World of Skew-distributed Outcomes, Research Policy 29(4-5): 559-66.

Schumpeter, J., (1934). Theory of Economic Development. Harvard University Press, Cambridge, MA. Schumpeter, J. A., 1942. Capitalism, socialism and democracy. New York: Harper and Row.

Shane, S., and Vankataraman, S., (2000) The promise of entrepreneurship as a field of research. Academy of Management Review, 26(1): 217-226.

Shane, S., (2000). Prior knowledge and the discovery of entrepreneurial opportunities. Organization science, 11(4), 448-469.

Shane, S., (2003) A General Theory of Entrepreneurship. The Individual-Opportunity Nexus, Cheltenham: Edward Elgar.

Stam, E., (2015). Entrepreneurial eco-systems and regional policy - a sympathetic critique. European Planning Studies, 23 (9), 1759-1769

Stam, E., and Spigel B., (2016). Entrepreneurial Ecosystems and Regional Policy, in Blackburn, R. et al (Eds) (2016). Sage Handbook for Entrepreneurship and Small Business: SAGE, 2016 
Stern, S., (2005). Economic Experiments: The Role of Entrepreneurship in Economic Prosperity. in Understanding Entrepreneurship: A Research and Policy Report, edited by Carl J. Schramm, 16-20. Ewing Marion Kauffman Foundation.

Thompson, P., and Chen, J., (2011). Disagreements, employee spinoffs and the choice of technology, Review of Economic Dynamics, 14(3), 455-474

Utterback, J. M,. (1996). Mastering the dynamics of innovation. Harvard Business Press.

Utterback, J. M., Meyer, M., Roberts, E., and Reitberger, G., (1988). Technology and industrial innovation in Sweden: A study of technology-based firms formed between 1965 and 1980. Research Policy, 17(1), 15-26

Van de Ven, A.H., (1993). The development of an infrastructure for entrepreneurship. Journal of Business Venturing 8, 211-230

Venkatarman, S., (1997) The distinctive domain of entrepreneurship re- search: an editor's perspective. In J. Katz, R. Brockhaus, (Eds) Advances in Entrepreneurship, Firm Emergence, and Growth, JAi Press, Greenwich, CT.

Wennberg, K., Wiklund, J., and Wright, M., (2011). The effectiveness of university knowledge spillovers: Performance differences between university spinoffs and corporate spinoffs. Research Policy, 40(8), 1128-1143.

Westlund, H., Larsson, J.P., and Rader Olsson, A., (2014). Startups and local entrepreneurial social capital in the municipalities of Sweden. Regional Studies, 48(6), 974-994

Williamson, O. E., (1975). Markets and hierarchies. New York,

Xiao, J., (2015). The effects of acquisition on the growth of new technology-based firms: do different types acquirers matter?. Small Business Economics, 45(3), 487-504

Zahra, S., Van de Velde, E., and Larraneta, B., (2007). Knowledge conversion capability and the growth of corporate and university spinoffs. Industrial and Corporate Change, 16 (4), 569-608. 